\title{
Introduction
}

One of the world's most widely known political parties is Front national (FN) in France. In 2007, something remarkable happened to this party. FN's vote share, which had been well over $10 \%$ at each national election since 1993 , fell to $4 \%$. What caused this sudden decline? This, we claim, was largely due to established parties' behaviour. It is an example of what we call the Parroting the Pariah Effect. In this book, we argue and demonstrate empirically that established parties can trigger this effect by combining two specific reactions to a particular other party. First, treating that party as a pariah-i.e., systematically boycotting it. Second, parroting the party-i.e., co-opting its policies. Through boycotting a party while co-opting its key policy issue positions, established parties can damage that party electorally. This way, established parties control the electoral marketplace.

By 2007 FN had been treated as a pariah for many years. The established French parties' decision to put the party in "republican quarantine" dates back to the 1980s (e.g., Mayer 2013). Since 1990 this agreement has been quite strictly enforced. Several centre-right regional leaders were even banished from their party because they had made deals with FN. On several occasions in the 1990s, the main parties repeated their refusal to cooperate with the party (e.g., Ivaldi 2007). Notwithstanding the republican quarantine FN flourished-except in the 2007 general election. In that election, the party lost many votes to the main centre-right party, whose leader, Nicolas Sarkozy, had policy stances similar to FN (Mayer 2007). In this study, we show that this Parroting

(C) The Author(s) 2018

J. van Spanje, Controlling the Electoral Marketplace, Political Campaigning and Communication, https://doi.org/10.1007/978-3-319-58202-3_1 
the Pariah Effect has occurred in many other times and places as well, allowing established parties to ward off competition.

Indeed, the strategy is quite common. In this book, we identify 39 occasions in post-war Western Europe on which a country's established parties have reacted in this way to a particular other party. Related to this, the strategy appears to be strikingly effective in the electoral arena. In 21 out of 39 cases, that party lost a quarter of its vote share or more. These cases include not only FN in France in 2007 but also Vlaams Belang (VB) in Flanders in 2010 as well as the Communist Parties of Switzerland in 1951 and Germany in 1953.

Despite its prevalence and effectiveness, the strategy has gone largely unnoticed in the relevant academic literature. This may be due to the lack of scholarly interest in established actors' reactions to challenger parties until a dozen years ago (Eatwell and Mudde 2004; Van Spanje and Van der Brug 2004). Another reason might be that the Parroting the Pariah Effect involves two types of reaction that are seldom studied in concert: Issue-based responses (such as parroting a party) revolve around party competition in terms of policy issue appeals, whereas non-issuebased reactions (such as treating a party as a pariah) concern competition in terms of other appeals. Moreover, the literature has typically focused on established parties' issue-based reactions only. The fact that nonissue-based responses, such as treating it as a pariah, have rarely been investigated is perhaps surprising, because they occur frequently, as we will see.

This study reinforces an existing trend toward taking into account the establishment's reactions to anti-immigration parties (Art 2011; Eatwell and Mudde 2004; Ivaldi 2007; Minkenberg 2006; Van Spanje and Van der Brug 2004, 2007, 2009). It focuses on an issue-based and a non-issue-based response, and their interaction. That interaction, the Parroting the Pariah Effect, is where our main focus lies-although we acknowledge the wide variety of established parties' responses to other parties. We concentrate on the consequences that this particular reaction has for the electoral performance of these other parties.

Which are these 'other parties' that established parties react to? Established parties typically respond to the emergence of parties that the political science literature often refers to as "anti-political-establishment parties" (Schedler 1996) or "niche parties" (Meguid 2005). These two party labels have in common that they mainly include communist and anti-immigration parties (e.g., Abedi 2004; Ezrow 2008). ${ }^{1}$ We follow 
this literature yet prefer to call these parties 'challengers.' This is because these parties are not necessarily anti-political-establishment, niche or single-issue (e.g., Mitra 1988; Mudde 1999) but they undeniably pose a challenge to the established parties in many ways. We define a challenger party as challenging the political status quo in ways that are widely considered beyond the pale. A challenger may be tiny but it may also attract many voters, receiving a substantial minority of the vote-as we will see. Obviously, challenger parties likely face strong reactions from other political actors. The larger the shares of the electorate of that time and place that feel the challenger's issue policy positions and/or campaign style are out of bounds, the smaller the other political actors' electoral risks of ostracising that party (cf. Van Spanje 2010). In this book, we concentrate on established parties' responses to the existence of challenger parties in their party system.

In so doing we enhance the relevant literature in four respects. First, existing analytical frameworks, most importantly spatial voting theory, revolve around issue-based established party reactions to a challenger party, such as adopting its policies. We refine spatial voting models to encompass a non-issue-based response with which parroting can be combined. This non-issue-based response is to treat the party as a pariah. Second, we empirically test propositions derived from this refined framework. In doing so, we show that two core hypotheses from the literature, the Parrot Hypothesis and the Pariah Hypothesis, do not hold up. Only by combining the two behaviours do we arrive at a hypothesisthe Parroting the Pariah Hypothesis - that we actually find evidence for. Third, in this book we extend existing analyses to include an oftenignored challenger party subset, Cold War communists. These parties, many of which were treated as pariahs, have typically been excluded from studies of challenger parties. ${ }^{2}$ Fourth, compared to earlier work we expand the empirical analysis by analysing more data points. We take into account more parties as well as a longer time period, which provides us with more statistical leverage. The theoretical underpinnings, datasets, and analyses are all new.

The Parroting the Pariah Effect is also important beyond its scientific relevance. First, many challenger parties are controversial, accused of political extremism or violence. Second, parroting them is equally controversial, in so far as the policies that these parties advocate are at odds with core legal or democratic principles. Third, treating parties as pariahs is controversial as well. It may keep politicians from government 
participation, and from functioning effectively in bodies to which they were elected. It, therefore, implies a (justified or unjustified) restriction of political competition (cf. Fennema and Maussen 2000) - and such competition is widely considered a necessary condition for democracy (e.g., Dahl 1971). This calls for maximally informed decisions on whether or not to treat a specific party as a pariah, which requires knowledge about the electoral effects of such decisions. The findings reported in this book may inform public debates about how democratic systems should deal with an unsavoury party - and with unsavoury behaviour by established parties in response to such a party.

\section{The Parrot Hypothesis}

In all democracies across the world, challenger parties emerge every now and then. How do established parties react? Although these parties respond in various ways, academic studies have mainly focused on their issue-based reactions. The dominant theory here is Spatial Theory of Electoral Competition (Downs 1957). This comes in two versions, Proximity Theory of Electoral Competition (e.g., Enelow and Hinich 1990) and Directional Theory of Electoral Competition (Rabinowitz and Macdonald 1989). Proximity Theory proposes that voters and parties are lined up along some axis of political contestation. Along that axis, parties can position themselves either closer to or farther away from another party. When parties position themselves closer to another party, standard theory predicts that this will affect the other party's vote share. For the study presented in this book, what is relevant is that a challenger party is predicted to be damaged electorally if established parties co-opt its policy positions.

In line with this, Downs $(2012,45)$ claims that a challenger party loses votes as a result of being imitated in terms of the policies it proposes. Downs (2001, 2002, 2012) distinguishes between "engage" and "disengage" strategies of the establishment. The category of "engage" strategies includes a "tolerant" one and a "militant" one. The tolerant one is the strategy to "collaborate" and the militant one is the strategy to "coopt." The last-mentioned strategy is the one that is discussed here: "To siphon back voters, policy co-optation requires mainstream parties to move away from the center" (Downs 2012, 45).

Another version of Spatial Theory of Electoral Competition is Directional Theory. Just as Proximity Theory, Directional Theory starts from the idea that parties and voters are lined up in some political spectrum. Unlike Proximity Theory, Directional Theory is about the intensity with which parties and 
voters feel committed to particular policies. A party can either emphasise or de-emphasise its commitment to a particular direction in which the polity should be heading. In this reasoning, established parties can thus outbid the challenger by committing more intensely to the policies it proposes - in which case this theory would hold that the challenger loses all votes to the established parties.

A more recent theory is the Position, Salience and Ownership (PSO) Theory of Electoral Competition. In this theory, Meguid $(2005,2008)$ mainly builds on Proximity Theory. She adds to this (among other things) that parties may also refrain from positioning themselves on a particular policy issue. By doing so they may succeed in making that issue less salient in voters' mind. For established parties this leads to three options of responses to a challenger party concerning its core policy issue: accommodative, adversarial and dismissive tactics (cf. Meguid 2005,2008 ). Both main left and main right parties can do so at the same time. Parroting the challenger falls under the rubric of accommodative tactics. According to PSO Theory, if both main parties apply such tactics, this costs the challenger votes.

The theoretical expectation that imitating a challenger party reduces its electoral support is called the Parrot Hypothesis in this book. Several scholars have posited some version of this hypothesis (e.g., Schain 2006). We have seen that three broad theories underlie the hypothesis: Based on Proximity Theory, established parties can move closer to the challenger; Based on Directional Theory, these parties can also emphasise their commitment to policies similar to those the challenger proposes; Based on PSO Theory, a more specific possibility is that both main parties simultaneously co-opt the challenger party's core issue. What all three theories have in common is that each of them predicts that the challenger loses out when it is aped by established parties.

Historically, parroted parties have included communist and anti-immigration parties, among others. Communist parties, for example, fared well in the first post-war elections in Switzerland, Germany, Finland and Iceland. In the election that followed, the main left and right parties in each of these four countries devoted more than 5\% of their manifesto to economic planning. This varied from $5.8 \%$ of the 1953 Christian Democratic Union manifesto in Germany to $18.5 \%$ of the 1951 Finnish Social Democrats' manifesto. As another case in point, anti-immigration parties did well in elections in the 2000s in France (FN), Flanders (VB), Denmark (DF) and Austria (FPÖ). The major parties' criticism of 
multiculturalism intensified over time. By the end of the decade, none of these countries' major parties failed to criticise the ideal of the multicultural society in their manifesto (own analysis of data from Volkens et al. 2014). Does this result in lower vote shares for challenger parties? In this book, we do not find consistent empirical evidence for the hypothesis that being parroted hurts them-see Chap. 5 .

\section{The Pariah Hypothesis}

Applying issue-based tactics is not the only way in which established parties react to a challenger party. Such a party often faces non-issue-based responses as well. A common non-issue-based reaction is to ostracise the challenger party. In this book, we define ostracism as systematically refusing to cooperate with it politically (cf. Van Spanje and Van der Brug 2004, 2007 and 2009; Van Spanje 2010). Examples of ostracised parties include communist and anti-immigration parties. In $1947 \mathrm{com}$ munist parties were ousted from government coalitions across Western Europe and subsequently ostracised (Tannahill 1978)-for example, in Switzerland and Germany. Several anti-immigration parties are currently being ostracised. For instance, FN is boycotted by all main French parties (Mayer 2013). As another example, VB has been completely isolated since five other Belgian parties signed a formal agreement to boycott the party in 1989 (Damen 2001).

Of all scholars who study challenger parties, only few mention these boycotts. One of these few scholars is Downs (2001, 2002 and 2012). In his distinction between "engage" and "disengage" strategies, the latter are either to "ignore" or to "isolate" the challenger party. On his view, isolating strategies can be divided into "legal restrictions" (de jure) and "blocking coalitions" (de facto). Clearly, ostracising a party is a "de facto isolation" reaction. In line with this, Strøm et al. (1994, 317) write that in building government coalitions in ten post-war parliamentary democracies "the systematic exclusion of certain parties from coalition bargaining is the most striking party constraint found with any regularity." For parties ruling out any government coalitions that include a particular rival, see Debus (2007), Geys et al. (2006), Martin and Stevenson (2001, 36-37, 46) and Strøm et al. (1994, 309).

That said, in this study we see ostracising a party as encompassing more than just pacts to block government coalitions with it. Ostracising a party often also involves various other measures. Many Cold-War 
communists, for instance, "were excluded not simply from governments and from governing majorities but from regular participation in bodies to which they were elected" (McInnes 1975, 167). So, ostracism involves the exclusion of a party from political cooperation in any way, and not only in terms of government coalition formation. ${ }^{3}$ Indeed, many party boycotts cannot be convincingly linked to coalition blocking. At the time that other parties agreed to ostracise them, FN and VB as well as the Swiss and German communists were fringe parties rather than potential governing partners. Thus, we extend Downs's coalition blocking category to, more generally, systematic refusals to politically cooperate. We consider a party a 'pariah' only if it is ruled out from all political cooperation. Cooperation between parties commonly includes-but is not limited to-joint press releases, electoral alliances, joint legislative activities, asking support for such activities, and giving support regarding such activities. All these forms of cooperation have been explicitly mentioned in, for example, Flemish parties' formal agreement to ostracise VB in 1989 (Damen 2001, 92).

The scarce literature on non-issue-based established party reactions is almost exclusively about reactions to anti-immigration parties (e.g., Downs 2012; Eatwell and Mudde 2004). History tells us, however, that various types of party have faced a boycott-including fascist, socialist, and Nazi parties (cf. Ingraham 1979). In this book, we examine both main challenger party types in post-war established democracies: communist parties and anti-immigration parties. We also try to be inclusive regarding types of political system and levels of government. At any level of government at which it operates, each party in any party system can be systematically boycotted by any of the other parties in that system.

Thus, the second hypothesis that we assess is what we refer to as the Pariah Hypothesis. This hypothesis holds that a party loses votes when treated as a pariah. We will outline the theoretical reasoning underpinning this hypothesis in Chap. 3. For now, suffice to say that no consistent empirical support is found for this hypothesis in this study. To illustrate this, let us here continue the example of the anti-immigration and communist parties. The French FN, the Flemish VB, and the German and Swiss communists have in common that they were consistently boycotted, whereas the Danish DF, the Austrian FPÖ and the Finnish and Icelandic communists were not. However, the electoral trajectories of these two sets of four parties do not suggest a clear pattern that would be consistent with the Pariah Hypothesis. In fact, in the 
Table 1.1 A typology of established party strategy to control the electoral marketplace

\begin{tabular}{lll}
\hline & $\begin{array}{l}\text { Treating challenger party } \\
\text { as a pariah }\end{array}$ & $\begin{array}{l}\text { Not treating challenger party } \\
\text { as a pariab }\end{array}$ \\
\hline $\begin{array}{ll}\text { Parroting challenger party } \\
\text { Not parroting challenger party }\end{array}$ & C & B \\
\hline
\end{tabular}

1990s the ostracised FN and VB increased their vote share at a more rapid pace than any of the four non-ostracised parties mentioned.

\section{The Argument in Brief}

Established parties might parrot a challenger party, and they might treat it as a pariah. These parties might also combine the reaction of parroting and the reaction of treating it as a pariah. Alternatively, established parties might refrain both from parroting the challenger and from treating it as a pariah. In sum, their efforts to control the electoral marketplace can be divided up according to four possible responses to challenger parties. Table l.l sums up the possibilities.

Table 1.1 reflects the idea that established parties can make a challenger party a parroted pariah (A), a parroted party that is not a pariah (B), a pariah that is not parroted (C), or a party that is neither parroted nor a pariah $(\mathrm{D})$. This is obviously a simplification of reality, as each of these categories lumps together several subcategories of established party reaction. For the purpose of our argument, however, we consider it a useful simplification.

In this book, we argue that a challenger party's electoral support is not reduced unless it is simultaneously parroted and treated as a pariah (A).

To further continue our examples, between 2007 and 2010 the major French, Flemish, Danish and Austrian right-wing parties adopted tough immigration stances. As the Parrot Hypothesis predicts, the French FN vote and the $\mathrm{VB}$ vote in Flanders plummeted. However, the vote for the DF in Denmark and the vote for the Austrian FPÖ remained stable. Similarly, between 1949 and 1953 the Swiss, German, Finnish and Icelandic social democratic parties embraced the idea of economic planning. Consistent with the Parrot Hypothesis, the Swiss and German 
communists subsequently lost more than a third of their national vote share. In defiance of that hypothesis, their Finnish and Icelandic comrades did not lose votes. What FN, VB and the Swiss and German communists have in common is that they were consistently boycotted. The DF, the FPÖ and the Finnish and Icelandic communists were not.

Similar arguments have been made in past research. However, there is a lack of clarity with regard to the concept of the anti-immigration party, the concept of parroting a party, and the concept of treating a party as a pariah. Moreover, these arguments (1) have never been fully elaborated in terms of which voters would defect, (2) have been made for anti-immigration parties only, (3) have been based on one or two observations only and (4) have never been rigorously tested. In a study of two parties, Art $(2006,8)$ argues that in the case of Germany "the most effective strategy" to "combat right-wing populist challengers" is a combination of boycotting and co-optation. Similarly, Rummens and Abts (2010, 663 ) contend that "a sustained strategy of containment combined with an attempt to provide democratic alternatives for dissatisfied voters will, in the end, convince extremist voters that their vote is indeed a wasted one." Their argument is tested empirically by Pauwels (2011). Based on interviews with 42 voters, Pauwels attributes VB's 2010 demise to its isolated position combined with other Belgian parties' copying its issue agenda. He also suggests that the same might have happened to FN in (2007)—as do Mayer (2007) and Shields (2010a, b). In a similar vein, Minkenberg $(2013,10)$ claims that FN's decline was due to "other parties' reactions" but does not elaborate on this.

In this book, we present clear conceptualisations and operationalisations of communist parties and of anti-immigration parties, and of parroting them and of treating them as a pariah. We provide a solid theoretical foundation for the mechanism underlying what we call the Parroting the Pariah Effect. In addition, we argue that the effect holds up not only for right-wing parties but also for left-wing ones, and in various political contexts, suggesting that this is a general phenomenon. Furthermore, we provide evidence for observable implications of our theory, including implications about which voters it involves. We do so using more data than any previous analysis. This way, we significantly improve upon the existing state of affairs, which is characterised by a lack of conceptual clarity, many hypotheses with little theoretical grounding, and no systematic or rigorous tests of these hypotheses. 


\section{How the Argument is Tested}

We show the existence of four phenomena in this book. First, that established parties often copy challenger party policies. Second, that established parties frequently ostracise challenger parties. Third, that challenger parties receive fewer votes when they become parroted pariahs. Fourth, that the losses parroted pariahs incur mainly concern policy-driven votes. The first two indicate that established parties often undertake efforts to control the electoral marketplace. The latter two show that these efforts can be quite effective. They are observable implications of our theory that policy-oriented voters abandon a party if it is treated as a pariah and parroted at the same time.

Comparisons are drawn within parties over time (parties that become parroted pariahs or parties that stop being parroted pariahs) and between parties (parroted pariahs versus their counterparts). We follow Lieberman's (2005) recommended strategy of "nested analysis." This means that we combine large $\mathrm{N}$ analysis with small $\mathrm{N}$ analysis. First, we show the first three phenomena (the two party strategies and the parroted pariahs losing) by way of a large $\mathrm{N}$ analysis, in which we include as many relevant cases as possible. Second, we conduct additional tests of the third phenomenon (parroted pariahs losing) in a small number of cases, selected on the basis of that large $\mathrm{N}$ analysis. This adds to the plausibility of our findings of the large $\mathrm{N}$ analysis. Furthermore, we show the existence of the fourth phenomenon (parroted pariahs losing policydriven votes) in this small $\mathrm{N}$ analysis. By using this mixed-method strategy, we combine the strengths of large and small $\mathrm{N}$ analysis to maximize the validity of our causal inferences. From these combined analyses a picture arises. This is the picture of established parties often trying to shut themselves off from electoral competition by challengers, in several cases with spectacular success.

A natural point to start the study of challenger parties is the liberation of Western Europe from Nazism in 1944-1945. The 15 independent European countries that have held successive democratic elections since that time constitute the countries under study. These are Austria, Belgium, Britain, Denmark, Germany, Finland, France, Iceland, Ireland, Italy, Luxembourg, the Netherlands, Norway, Sweden, and Switzerland. ${ }^{4}$ In each of these countries, the largest party that defines itself as 'communist' - no matter the precise meaning that it may attribute to this termis selected for the analysis. In addition, 13 parties in these countries are 
identified as 'anti-immigration' (cf. Fennema 1997; Van Spanje 2011). There are other parties that have been considered anti-immigration as well but only for these 13 we have data supporting this claim. Our selection of challenger parties closely resembles that of other comparative studies of these parties (e.g., Meguid 2005; Adams et al. 2006; Ezrow $2008)^{5}$ albeit that we include substantially more parties and study them over a substantially longer period: 1944-2014. We have rerun our most comprehensive analyses based on exactly the same parties as Meguid (2005)—see Appendix A.

Each of these parties we code as 'parroted' or not and as 'pariah' or not at each national-level election. We thus focus on parrots and pariahs at the national level. ${ }^{6}$ This is because the national level is where interparty behaviour is bound to have the greatest impact on the electorate. After all, both voters and parties consider national elections the most important elections (cf. Reif and Schmitt 1980; Franklin and Hobolt 2011). The challenger parties are classified as 'parroted' or not, and as 'pariah' or not, based on an assessment of their largest established rival's reactions. The attitude of the established left is generally crucial for communist parties' chances of influencing policy-making, and the established right for anti-immigration parties' chances. In any case, voters' party choice is not expected to be affected by the mere fact that ideologically remote parties imitate a challenger party, or keep it at arm's length while its natural allies do not. The idea that the response of only one party is key for the challenger party is in line with the consistent finding that electoral competition between the left and the right bloc is outweighed by the electoral competition within each bloc in Western Europe (Bartolini and Mair 1990). In addition, it is analogous to Hug's (2001, 62-63) work on new party emergence: "there is usually only one established party whose reaction to a given demand has a vital impact on whether a new party does or does not emerge. Our assumption relies, therefore, on the argument that, with respect to the potential new party, only the response of one established party is important in the decision as to whether to form a new party or not."

As in Hug's (2001) study, in this book parties will be perceived as single, unitary actors; we abstract from intra-party competition. Admittedly, this assumption entails a substantial simplification of reality. It also sets constraints on what we can investigate. Just as an example, we do not investigate ways in which parties use their control over rank and file to keep unpalatable issues from making it onto party platforms, and how 
this can result in important policies being neglected in public debateas arguably was the case for issues related to immigration in some West European countries in the 1980s. But in defence of this approach, it can be said that one cannot have theory without simplification, and for the purposes of this study this is a necessary simplification (cf. Laver and Schofield 1990; Strøm 1990). In a next step, we use the classifications as 'parroted' or not and as 'pariah' or not as independent variables in analyses explaining electoral support for the challenger parties.

\section{Plan of THE BOOK}

This book contains seven chapters. After this introductory chapter, Chap. 2 discusses the hypothesis that established parties' parroting a challenger party reduces its electoral support, the Parrot Hypothesis. Chapter 3 introduces the Pariah Hypothesis, which holds that a challenger party loses votes if it is treated as a pariah by established parties. In the three chapters after that we propose a third hypothesis, the Parroting the Pariah Hypothesis, and present empirical evidence in support of it. This is our book's core thesis, which holds that a challenger party loses a substantial share of its electoral support if established parties both parrot it and treat it as a pariah. In the fourth chapter, we lay out the theoretical framework underlying that hypothesis. In the two subsequent chapters, we show evidence for it, using aggregate-level data from national-level election results and the coding of party manifestos (Chap. 5 ) and employing individual-level data derived from experimental and non-experimental research (Chap. 6). The book's concluding chapter summarises the findings, discusses the limitations of the study as well as theoretical and practical implications. It concludes by discussing various avenues for further research.

\section{Notes}

1. At the end of Chap. 5 we show findings with as well as without communist parties, as no consensus exists about the "nicheness" of Cold War communist parties in Western Europe (Meyer and Wagner 2013; Meyer and Miller 2015; Wagner 2012).

2. Whereas post-1989 communist parties have been studied as "niche parties" in past research (Adams, Clark, Ezrow, and Glasgow 2006; Ezrow 2008), pre-1989 communist parties have not. 
3. Alternatives to the dichotomous conceptualisation of ostracism and nonostracism include a tripartite classification in which a party is (by the relevant other) 'ostracised all the time,' 'ostracised most of the time,' or 'not ostracised,' or a continuum ranging from 'ostracism' to 'no ostracism.' If the criterion of complete refusal to cooperate is relaxed, a party might complete legislative majorities in minority parliamentarism and gain some policy benefits while the exclusion from government participation is maintained (see also Downs 2002). These would not provide better ways of capturing the most important empirical lines of demarcation, however, as the strategy of ostracism is expected theoretically to work only when consistently applied to all types of political collaboration with a particular party. As the sparse data on the topic do not allow for rigorous testing of this proposition, we use the dichotomous conceptualisation in this book.

4. Malta became an independent state in 1964. Although free and fair elections were held in Malta before that time, it, therefore, does not satisfy the criterion mentioned.

5. Some studies also study green parties. However, adding greens to the analysis is simply not helpful. This is because none of these parties have been consistently ostracised by their largest mainstream competitor as far as we are aware (cf. Debus 2007). See the robustness checks in Chap. 5 and also Appendix A for analyses in which greens have nonetheless been included.

6. With regard to this operationalisation of ostracism, it is problematic that parties may have been ostracised at other levels but not at the national level, or vice versa. Future research should address the question of to what extent such differences have occurred, and to what extent this changes our conclusions about voting behaviour in national-level elections.

\section{REFERENCES}

Abedi, Amir. 2004. Anti-Political Establishment Parties: A Comparative Analysis. London: Routledge.

Adams, James, Michael Clark, Lawrence Ezrow, and Garrett Glasgow. 2006. Are Niche Parties Fundamentally Different from Mainstream Parties? the Causes and the Electoral Consequences of Western European Parties' Policy Shifts, 1976-1998. American Journal of Political Science 50 (3): 513-529.

Art, David. 2006. The Politics of the Nazi Past in Germany and Austria. New York: Cambridge University Press.

Art, David. 2011. Inside the Radical Right. The Development of Anti-Immigrant Parties in Western Europe. New York: Cambridge University Press.

Bartolini, Stefano, and Peter Mair. 1990. Policy Competition, Spatial Distance and Electoral Instability. West European Politics 13 (4): 1-16. 
Dahl, Robert A. 1971. Polyarchy, Participation, and Opposition. New Haven, NJ: Yale University Press.

Damen, Sofie. 2001. Strategieën tegen extreem-rechts: Het cordon sanitaire onder de loep. Tijdschrift voor Sociologie 22 (1): 89-110.

Debus, Marc. 2007. Pre-Electoral Alliances, Coalition Rejections, and Multiparty Governments. Baden-Baden: Nomos.

Downs, Anthony. 1957. An Economic Theory of Democracy. New York: Harper and Row.

Downs, William M. 2001. Pariahs in their Midst: Belgian and Norwegian Parties React to Extremist Threats. West European Politics 24 (3): 23-42.

Downs, William M. 2002. How Effective is the Cordon Sanitaire? Lessons from Efforts to Contain the Far Right in Belgium, France, Denmark and Norway. Journal für Konflikt- und Gewaltforschung 4 (1): 32-51.

Downs, William M. 2012. Political Extremism in Democracies: Combating Intolerance. New York: Palgrave Macmillan.

Eatwell, Roger, and Cas Mudde. 2004. Western Democracies and the Right Extremist Challenge. London: Routledge.

Enelow, James M., and Melvin J. Hinich. 1990. Advances in the Spatial Theory of Voting. Cambridge: Cambridge University Press.

Ezrow, Lawrence. 2008. On the inverse relationship between votes and proximity for niche parties. European Journal of Political Research 47: 206-220.

Fennema, Meindert. 1997. Some conceptual issues and problems in the comparison of anti-immigrant parties in Western Europe. Party Politics 3: 473-492.

Fennema, Meindert, and Marcel Maussen. 2000. Dealing with Extremists in Public Discussion: Front National and 'Republican Front' in France. Journal of Political Philosophy 8 (3): 379-400.

Franklin, Mark N., and Sara B. Hobolt. 2011. The legacy of lethargy: How elections to the European Parliament depress turnout. Electoral Studies 30 (1): 67-76.

Geys, Benny, Bruno Heyndels, and Jan Vermeir. 2006. Explaining the formation of minimal winning coalitions: Anti-system parties and anti-pact rules. European Journal of Political Research 45: 957-984.

Hug, Simon. 2001. Altering Party Systems: Strategic Behavior and the Emergence of New Political Parties in Western Democracies. Ann Arbor, MI: University of Michigan Press.

Ingraham, Barton L. 1979. Political Crime in Europe: A Comparative Study of France, Germany, and England. Los Angeles: University of California Press.

Ivaldi, Gilles. 2007. The Front national vis-à-vis power in France: factors of political isolation and performance assessment of the extreme right in municipal office. In The extreme right parties and power in Europe, ed. P. Delwit and P. Poirier. Bruxelles: Editions de l'Université de Bruxelles. 
Laver, Michael J., and Norman Schofield. 1990. Multiparty government: The politics of coalition in Europe. Oxford: Oxford University Press.

Lieberman, Evan S. 2005. Nested Analysis as a Mixed-Method Strategy for Comparative Research. American Political Science Review 99 (3): 435-452.

Martin, Lanny W., and Randolph T. Stevenson. 2001. Government Formation in Parliamentary Democracies. American Journal of Political Science 45 (1): $33-50$.

Mayer, Nonna. 2007. Comment Nicolas Sarkozy a rétréci l'électorat Le Pen. Revue française de science politique 57 (3-4): 429-445.

Mayer, Nonna. 2013. From Jean-Marie to Marine Le Pen: Electoral Change on the Far Right. Parliamentary Affairs 66 (1): 160-178.

McInnes, Neil. 1975. The Communist Parties of Western Europe. London: Oxford University Press.

Meguid, Bonnie M. 2008. Party Competition Between Unequals: Strategies and Electoral Fortunes in Western Europe. New York: Cambridge University Press.

Meyer, Thomas M., and Bernhard Miller. 2015. The Niche Party Concept and its Measurement. Party Politics 21 (2): 259-271.

Meyer, Thomas M., and Markus Wagner. 2013. Mainstream of Niche? VoteSeeking Incentives and the Programmatic Strategies of Political Parties. Comparative Political Studies 46 (10): 1246-1272.

Minkenberg, Michael. 2006. Repression and Reaction: Militant Democracy and the Radical Right in Germany and France. Patterns of Prejudice 40 (1): $25-44$.

Minkenberg, Michael. 2013. From Pariah to Policy-Maker? The Radical Right in Europe, West and East: Between Margin and Mainstream. Journal of Contemporary European Studies 21 (1): 5-24.

Mitra, Subrata. 1988. The national front in France-a single issue movement? West European Politics 11 (2): 47-64.

Mudde, Cas. 1999. The single-issue party thesis. Extreme right parties and the immigration issue. West European Politics 22 (3): 182-197.

Pauwels, Teun. 2011. Explaining the Strange Decline of the Populist Radical Right Vlaams Belang in Belgium: The Impact of Permanent Opposition. Acta Politica 46 (1): 60-82.

Rabinowitz, George, and Stuart E. Macdonald. 1989. A Directional Theory of Issue Voting. American Political Science Review 83 (1): 93-121.

Reif, Karlheinz, and Hermann Schmitt. 1980. Nine second-order national elections: A conceptual framework for the analysis of European election results. European Journal of Political Research 8 (1): 3-44.

Rummens, Stefan, and Koenraad Abts. 2010. Defending Democracy: The Concentric Containment of Political Extremism. Political Studies 58: 649665. 
Schain, Martin A. 2006. The Extreme-Right and Immigration Policy-Making: Measuring Direct and Indirect Effects. West European Politics 29 (2): 270-89.

Schedler, Andreas. 1996. Anti-Political-Establishment Parties. Party Politics 2 (3): 291-312.

Shields, Jim. 2010a. Support for Le Pen in France: Two Elections in Trompe l'ail. Politics 30 (1): 61-69.

Shields, Jim. 2010b. The Far-Right Vote in France: From Consolidation to Collapse? French Politics, Culture and Society 28 (1): 25-45.

Van Spanje, Joost H. P. 2010. Parties beyond the pale. Why some political parties are ostracized by their competitors while others are not. Comparative European Politics 8 (3): 354-383.

Van Spanje, Joost H. P. 2011. The wrong and the right. A comparative analysis of 'anti-immigration' and 'far right' parties in contemporary Western Europe. Government and Opposition 46 (3): 293-320.

Van Spanje, Joost H. P., and Wouter van der Brug. 2007. The Party as Pariah: The Exclusion of Anti-Immigration Parties and its Effect on their Ideological Positions. West European Politics 30 (5): 1022-1040.

Van Spanje, Joost H. P., and Wouter van der Brug. 2009. Being intolerant of the intolerant. The exclusion of Western European anti-immigration parties and its consequences for party choice. Acta Politica 44 (4): 353-384.

Strøm, Kaare. 1990. A Behavioral Theory of Competitive Political Parties. American Journal of Political Science 34: 565-598.

Strøm, Kaare, Ian Budge, and Michael Laver. 1994. Constraints on Cabinet Formation in Parliamentary Democracies. American Journal of Political Science 38 (2): 303-335.

Tannahill, R. Neal. 1978. The Communist Parties of Western Europe. A Comparative Study. Westport, CT: Greenwood.

Van Spanje, Joost H. P., and Wouter Van der Brug. 2004. Consequences of the strategy of a 'cordon sanitaire' against anti-immigrant parties. Paper read at ECPR Joint Sessions of Workshops, at Uppsala University.

Volkens, Andrea, Pola Lehmann, Nicolas Merz, Sven Regel, and Annika Werner. 2014. The Manifesto Data Collection, Manifesto Project (MRG/CMP/ MARPOR). Berlin: WZB.

Wagner, Markus. 2012. Defining and Measuring Niche Parties. Party Politics 18 (6): 845-864. 


\section{焦 Springer}

http://www.springer.com/978-3-319-58201-6

Controlling the Electoral Marketplace

How Established Parties Ward Off Competition van Spanje, J.

2018, XIV, 182 p. 22 illus., Hardcover

ISBN: 978-3-319-58201-6 